Article

\title{
Indium Mineralization in a Sn-Poor Skarn Deposit: A Case Study of the Qibaoshan Deposit, South China
}

\author{
Jianping Liu ${ }^{1,2}$ \\ 1 Key Laboratory of Metallogenic Prediction of Non-ferrous Metals and Geological Environment Monitor, \\ Central South University, Changsha 410083, China; liujianping@csu.edu.cn; Tel.: +86-731-888-30616 \\ 2 Key Laboratory of Mineralogy and Metallogeny, Guangzhou Institute of Geochemistry, \\ Chinese Academy of Sciences, Guangzhou 510460, China
}

Academic Editor: Raymond M. Coveney Jr.

Received: 6 March 2017; Accepted: 10 May 2017; Published: 12 May 2017

\begin{abstract}
Indium (In) is commonly hosted in Sn-rich deposits but rarely reported in Sn-poor deposits. However, an In-rich and Sn-poor skarn deposit, the Qibaoshan $\mathrm{Cu}-\mathrm{Zn}$-Pb deposit, has been identified in south China. Geochemical analyses were undertaken on 23 samples representing the following mineral assemblages: sphalerite-pyrite, pyrite-chalcopyrite, pyrite-sphalerite-galena-chalcopyrite, pyrite, magnetite-pyrite, and magnetite. The results show that In is richest in the sphalerite-pyrite ores, with concentrations of 28.9-203.0 ppm (average $122.8 \mathrm{ppm}$ ) and $1000 \mathrm{In} / \mathrm{Zn}$ values of 2.7-10.9 (average 7.0). Other ore types in the Qibaoshan deposit are In poor, whereas all are Sn poor (10 to $150 \mathrm{ppm}$ ), with most samples having Sn concentrations of $\leq 70 \mathrm{ppm}$. Indium is mainly hosted by sphalerite, as inferred from the strong correlation between In and $\mathrm{Zn}$, and weak correlation between In and Sn. Mineral paragenetic relationships indicate sphalerite formed from late quartz-sulfide stage of mineralization processes. Indium in the Qibaoshan deposit is richer in vein-type orebodies than in lenticular-type orebodies occurring at contact zones between carbonate and quartz porphyry, or in carbonate xenoliths. Igneous intrusions that were Sn poor and emplaced at shallow depths formed the In-rich orebodies of the Qibaoshan deposit.
\end{abstract}

Keywords: indium; Sn-poor deposit; skarn type; Qibaoshan deposit; south China

\section{Introduction}

With indium (In) being widely used in high-technology applications, it is important for geologists to understand the development of In deposits [1-3]. Indium is hosted by many deposit types [1], and industrial In resources are generally associated with massive sulfide, granite-related vein, skarn, and disseminated deposits [2,4]. Although In occurs mainly in an isomorphic form in sphalerite, important resources are hosted in Sn-rich deposits. Examples include Sn-polymetallic deposits in south China [5-7], Bolivia [8], Japan [2,4], and some Sn-rich Cu-Zn deposits within the Iberian Pyrite Belt [9-11] and the Meng'entaolegai Ag- $\mathrm{Pb}-\mathrm{Zn}$ deposit in north China [12]. Considering these associations with Sn-rich mineralization, could In-rich deposits also occur in Sn-poor environments?

According to limited geochemical and mineralogical data, the following ore deposits may be classified as Sn-poor but In-rich based on summaries of 104 In-bearing deposits by Schwarz-Schampera and Herzig (2002) [1]. Volcanogenic massive sulfide deposits at Brunswick No. 12 and Health Steele in New Brunswick, Canada, contain average values of 49-69 and 50 ppm In, respectively [1]. The Zulova polymetallic vein-type deposit in the Bohemian Massif of Czechoslovakia has an average value of 52 ppm In. The epithermal Prasolov deposit at Kunashir Island, Kuriles, Russia, and the Karamazar skarn deposit in Uzbekistan have average values of 20 and 35 ppm In, respectively. Active seafloor hydrothermal vent sites include the Southern Lau Basin in the South Pacific (average 78 ppm In) [1,13]; the Eastern Manus Basin (average 57 ppm In) at Manus-Kilinailau, Papua, New Guinea [14]; and 
Snake Pit (average $29 \mathrm{ppm}$ In) on the Mid-Atlantic Ridge at $23^{\circ} \mathrm{N}$ [15]. In addition, the Kudryavy Volcano (average 20 ppm In) on Iturup Island, Russia, represents an active magmatic system [16,17]. These examples illustrate the existence of In-rich mineralization in Sn-poor deposits, but no detailed study has been conducted on this deposit type. Therefore, further research is required to document the geology, mineralogy, and geochemistry of In-rich and Sn-poor deposits.

South China contains significant In mineralization and important deposits occur in Yunnan, Guangxi, Guangdong and south Hunan provinces (Figure 1a). The In deposits of south China commonly occur within Sn belts [18] and include Dachang in the Nandan-Hechi Sn belt of northwest Guangxi [19], and Dulong [6] and Gejiu [20] in the southeastern Yunan Sn belt [21]. In contrast, In mineralization in the northeastern Hunan province (NEH) occurs within a $\mathrm{Cu}-\mathrm{Au}$ belt. The Qibaoshan $\mathrm{Cu}-\mathrm{Zn}$ - $\mathrm{Pb}$ deposit is the largest of these deposits in the NEH, with $\sim 585 \mathrm{t}$ In [22,23], and provides a type example to study In mineralization in a Sn-poor setting.

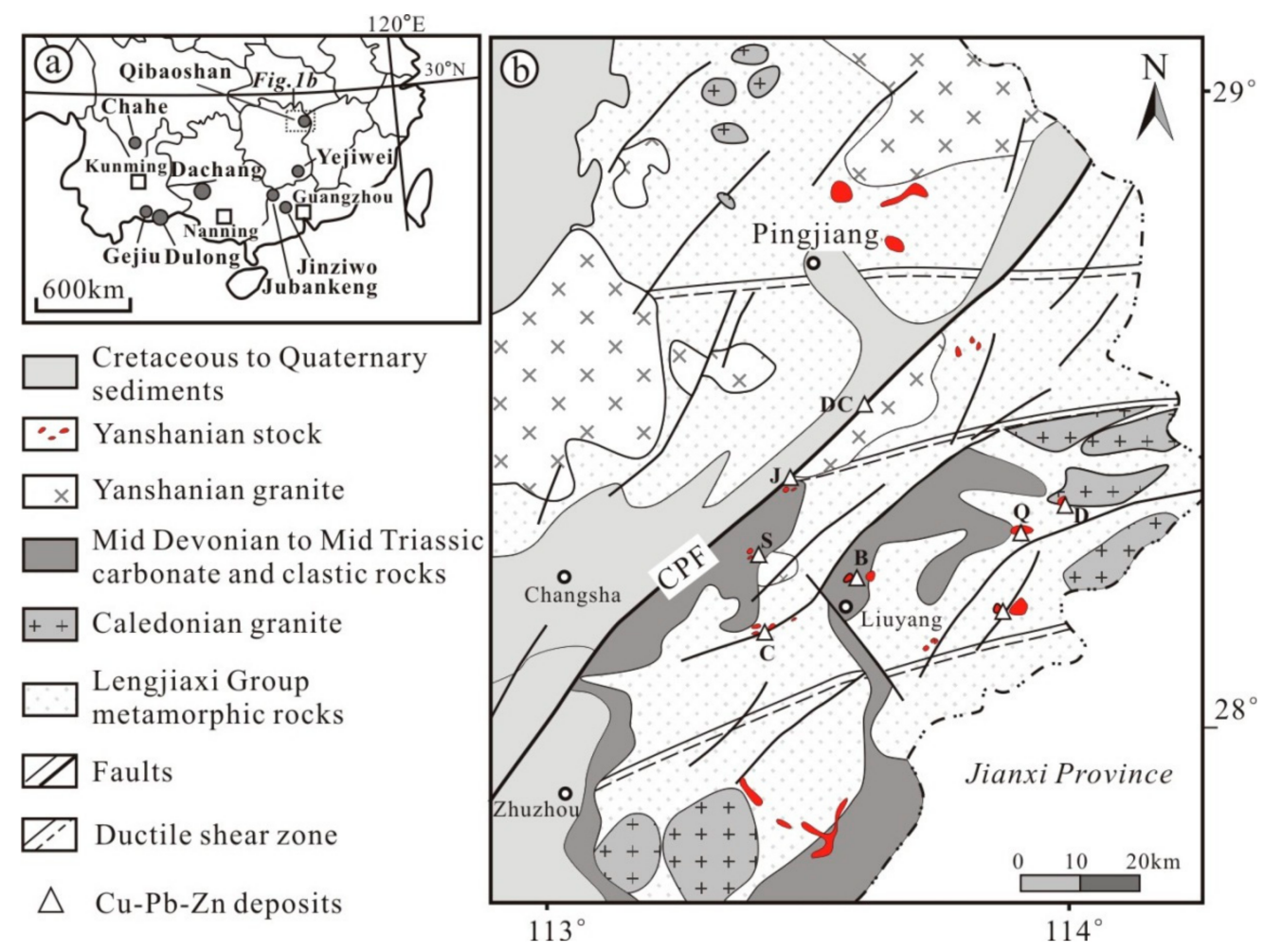

Figure 1. (a) Location map of In-bearing deposits in south China (after [24]). (b) Regional geological map of northeastern Hunan province (after [25-27]) showing $\mathrm{Cu}-\mathrm{Pb}-\mathrm{Zn}$ deposits related to Yangshanian stocks, southeast of the Changsha-Pingjiang Fault (CPF). Abbreviations: DC = Dongchong Cu-Co deposit; $\mathrm{J}$ = Jingchong $\mathrm{Cu}$ deposit; $\mathrm{S}=$ Shitangchong $\mathrm{Cu}$ deposit; $\mathrm{C}=$ Chengchong $\mathrm{Cu}$ deposit; $\mathrm{B}=$ Bieyushan $\mathrm{Pb}-\mathrm{Zn}$ deposit; $\mathrm{D}=$ Donggangshan $\mathrm{Cu}$ deposit; and $\mathrm{Q}=$ Qibaoshan $\mathrm{Cu}-\mathrm{Zn}-\mathrm{Pb}$ deposit.

Exploration of the Qibaoshan deposit occurred from 1958 to 1971, and the No. 402 Geological Team of the Hunan Bureau of Geology and Mineral Resources (HBGMR) identified 280,000 t Cu, 520,000 t $\mathrm{Zn}, 60,000 \mathrm{t} \mathrm{Pb}$, and $40 \mathrm{Mt}$ pyrite with associated Au-Ag-Ge-Ga-In-Cd [23]. This paper presents new geochemical and mineralogical data that are used to develop a genetic model for In mineralization in the Sn-poor Qibaoshan skarn deposit. 


\section{Regional and Local Geology}

\subsection{Regional Geology of Northeastern Hunan Province}

The Qibaoshan deposit is located $\sim 90 \mathrm{~km}$ east of Changsha City, southern China. In a tectonic sense, the NEH is located within the central part of the Jiangnan orogenic belt. Lithostratigraphic units in the NEH include Neoproterozoic low-grade metamorphic rocks of the Lengjiaxi Group, Mid-Devonian to Mid-Triassic shallow marine clastic-carbonate rocks, and Meso-Cenozoic red-bed sedimentary rocks (Figure 1b) [27]. The Lengiiaxi Group is widely distributed in the NEH and consists of sericite phyllite and quartz-sericite phyllite, with a thickness of $\geq 25,000 \mathrm{~m}$ [28]. Mid-Devonian to lower Carboniferous rocks are terrigenous clastic units, and upper Carboniferous to Permian rocks are carbonates. Structural basins separated by NNE-NE trending faults in the NEH contain Meso-Cenozoic red-bed sedimentary rocks (Figure 1b) [29].

The NEH experienced multiple periods of granitic magmatism from the Neoproterozoic to Early Cretaceous. Dominant periods are marked by Caledonian and Yanshanian granites [25,29-33], with early Yanshanian (160-140 Ma) granites [27,34,35] being most abundant in the NEH. These granites are subdivided into two types based on size and geochemical features [26]. The first type comprises large plutons (10-1000 km²) northwest of the Changsha-Pingjiang Fault (CPF; Figure 1b), which are S-type or fractionated S-type granites [33] (e.g., the Mufushan, Wangxiang, and Jinjing plutons). The second type comprises stocks and dykes (e.g., Qibaoshan and Bieyushan) that occur southeast of the CPF (Figure 1b). Fault intersections controlled the emplacement of these diorite-granite porphyry and quartz porphyry intrusions that measure $\leq 1 \mathrm{~km}^{2}$ to several $\mathrm{km}^{2}$ in surface area. Although geochemical and mineralogical data are limited, these igneous rocks are classified as I-type granites based on the assemblage of accessory minerals $[25,26]$.

Numerous gold and base metal deposits occur throughout the NEH. Gold deposits hosted by the Lengjiaxi Group occur in quartz veins, altered slates, and breccia within ductile shear zones (e.g., the Wangu [36], Huangjindong, Yanlinshi, and Hongyuan gold deposits [27,37]). Base metal mineralization in vein, skarn, and porphyry-type deposits is associated with I-type granites south of the CPF (Figure 1b) [26], with copper being the dominant mineral resource. Deposits include the vein-type $\mathrm{Zn}-\mathrm{Pb}-\mathrm{Cu}$ Dongchong [26,38], vein-type $\mathrm{Co}-\mathrm{Cu}$ Jingchong [39,40], and skarn-type $\mathrm{Cu}-\mathrm{Zn}$-Pb Qibaoshan [28]. Additional mineral occurrences were explored during the 1950s to 1980s (e.g., Shitangchong $\mathrm{Pb}-\mathrm{Zn}-\mathrm{Cu}$ vein, Bieyushan $\mathrm{Pb}-\mathrm{Zn}-\mathrm{Cu}$ porphyry, Zhangchong-Mazhichong $\mathrm{Cu}$ veins, and Dongmaoshan Cu-Mo veins $[26,34,39])$. However, the largest base metal deposit in the NEH is the Qibaoshan deposit, which contains skarn and vein-type mineralization.

\subsection{Geology of the Qibaoshan Deposit}

\subsubsection{Stratigraphy}

Rock units of the Qibaoshan deposit, as exposed in outcrop, include the Lengjiaxi Group, the Lower Nanhua Liantuo Formation, and Carboniferous and Quaternary sediments (Figure 2a) [28,41]. Sericite-phyllite and quartz-sericite-phyllite strata of the Lengiiaxi Group occur at the north and south of the deposit. An unconformity separates the Lengjiaxi Group from the underlying Liantuo Formation. North of the mine, a lower unit of quartzite and an upper unit of slate and metamorphosed siltstone make up the Liantuo Formation. Rocks of the lower Carboniferous Datang Formation consist of shale, siltstone, and conglomerate [28]. Mudstone, limestone and medium-grained dolomite make up the middle to upper Carboniferous Hutian Formation [28], which hosts the lenticular-type orebodies of the Qibaoshan deposit [22].

\subsubsection{Intrusive Rocks}

Mineralization in the Qibaoshan deposit is related to a complex of quartz porphyry stocks that comprise three phases $[28,42,43]$. The emplacement of this complex was controlled by the F1 and F2 
faults (Figure 2a). The first phase, quartz porphyry 1 (Q1), is a mushroom-shape body measuring $6000 \mathrm{~m}$ long (E-W) and 10 to $1000 \mathrm{~m}$ wide (N-S), with a surface area of $\sim 1.7 \mathrm{~km}^{2}$ [41]. In the southeast edge of the intrusion, breccias within the F2 Fault and suborder faults contain clasts of slate and limestone (Figure 2a). Dykes of Q1 extend from this northwest-trending intrusion at intersections with the F2 Fault and secondary faults. Texturally, Q1 contains phenocrysts of quartz (5-15 vol \%), feldspar (10-20 vol \%), and biotite (2-3 vol \%) set in a microcrystalline groundmass containing sericite, clay minerals, and fine quartz [28]. Quartz porphyry 1 was intruded by a small body $\left(\sim 0.3 \mathrm{~km}^{2}\right)$ of quartz porphyry $2(\mathrm{Q} 2)$, near the mine's center (Figure $2 a)$, whereas to the east and west, Q2 occurs as dykes along the F2 Fault [44]. Although Q1 and Q2 have similar mineral assemblages, they differ as follows [28]: (1) quartz phenocrysts in Q2 (0.8-3.4 $\mathrm{mm})$ are larger than those in Q1 (0.6-2.2 $\mathrm{mm})$; (2) quartz grains in Q1 are white and opaque; (3) feldspar phenocrysts in Q2 (0.3-3.4 mm) are larger than those in Q1 (0.4-1.7 mm); and (4) clay minerals produced by weathering of Q2 and Q1 are montmorillonite and kaolinite, respectively.
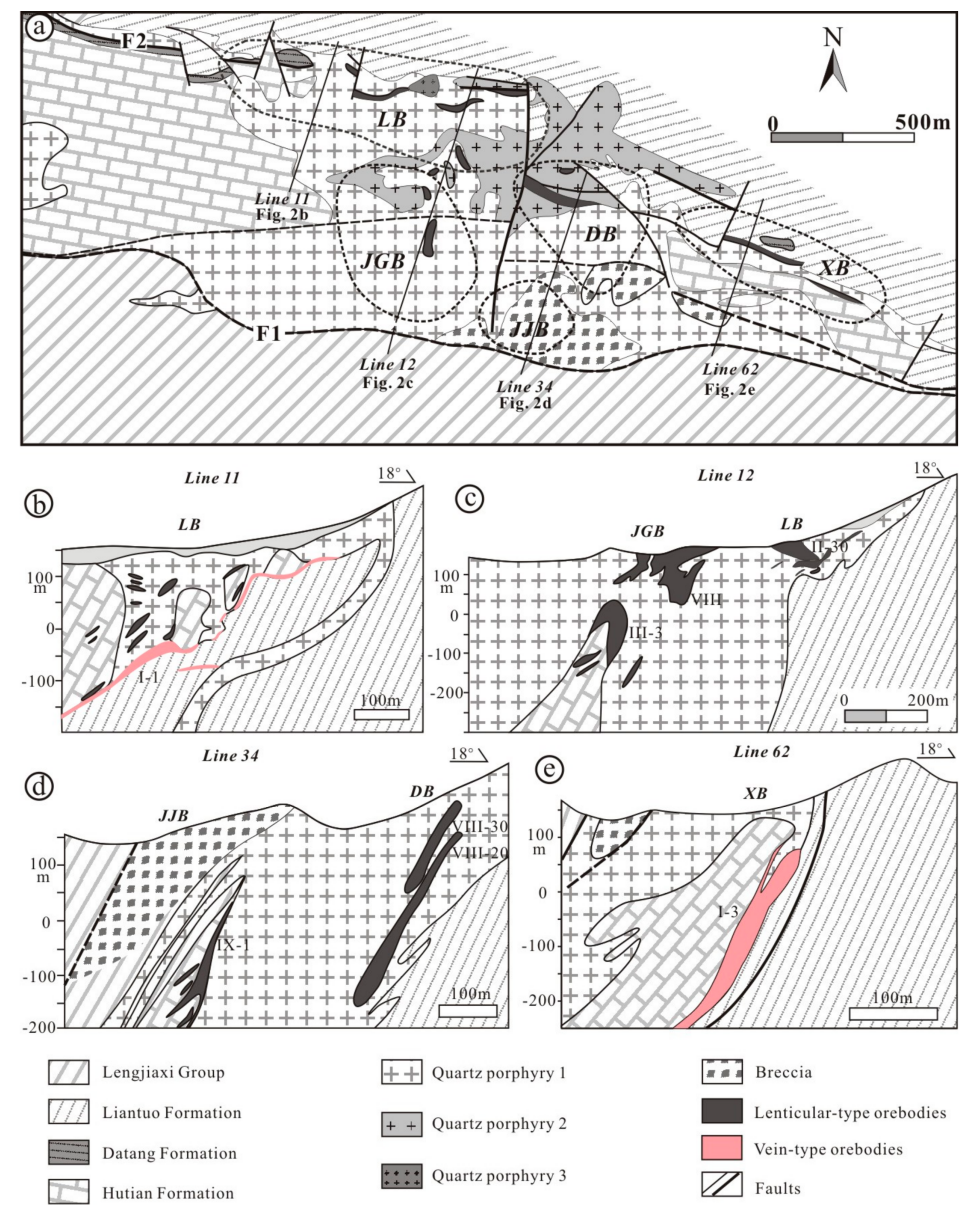

Figure 2. (a) Geologic map of the Qibaoshan deposit (after [28]). (b) Cross-section of the No. 11 prospecting line. (c) Cross-section of the No. 12 prospecting line. (d) Cross-section of the No. 34 prospecting line ((b-d) are after the No. 402 Geological Team, unpublished data). (e) Cross-section of the No. 62 prospecting line (after [45]). Abbreviations: LB = Laohukou Block; DB = Daqibaoshan Block; $\mathrm{XB}=$ Xiaoqibaoshan Block; JGB = Jigongwan Block; and JJB = Jiangjiawan Block.

The third phase, quartz porphyry 3 (Q3), occurs in the northern part of the mine and has a sub-round shape measuring $165 \mathrm{~m} \times 120 \mathrm{~m}$ [28]. Phenocrysts consist of quartz, feldspar, biotite, and trace hornblende [45], which are smaller $(<1 \mathrm{~mm})$ than those in Q1 and Q2 [28]. Phenocrysts in Q3 occur in a groundmass of feldspar, cryptocrystalline quartz, and fine biotite. The mineralogy and 
geochemistry of the three phases indicate Q1 is pre-mineralization, Q2 is syn-mineralization, and Q3 is post-mineralization [41].

Zircon from Q1 yields an LA-ICP-MS U-Pb age of $155 \mathrm{Ma}$ [46], indicating the Qibaoshan intrusion formed during an early stage of magmatism in the NEH [33]. Mineralogical and geochemical data, including $\mathrm{A} / \mathrm{NCK}=1.1-3.3$ [47], $\mathrm{Na}_{2} \mathrm{O}(0.4-0.5 \mathrm{wt} \%)<\mathrm{K}_{2} \mathrm{O}(1.5-6.8 \mathrm{wt} \%)$, and a CIPW normative corundum content of $5.4 \mathrm{wt} \%$ [48], indicate the Qibaoshan quartz porphyry is an S-type granite. However, slightly negative Eu anomalies [47] and magnetite $>$ ilmenite are features of I-type granites [28]. Petrogeochemistry and Hf isotopes for zircons indicate the quartz porphyry magma originated from a crustal source, with mantle input [46,47].

\subsubsection{Orebodies in the Qibaoshan Deposit}

Mineralization occurs at the contact between the quartz porphyry intrusion and carbonate rocks, within a carbonate xenolith hosted by quartz porphyry, and along the unconformity between the Datang and Liantuo formations (Figure 2b-e) [42,45]. Exploration for Cu, S, and Fe occurred from 1950 through the 1960s, when 208 orebodies, including the six largest (e.g., Nos I-1, I-3, III-3, VII-20, VIII-30, and IX-1), were discovered Orebodies are divided into lenticular-type and vein-type based on shape, host rocks, and mineralogy. Lenticular-type orebodies occur at the contact between intrusions and carbonate rocks, in contrast to the vein-type orebodies that occur along faults. The Qibaoshan deposit is divided into five blocks relative to the location of quartz porphyry (Figure 2a) [28,49]. Northeast of the quartz porphyry are the Laohukou Block (LB), the Daqibaoshan Block (DB), and the Xiaoqibaoshan Block (XB), whereas the Jigongwan Block (JGB) and Jiangjiawan Block (JJB) occur southwest of the quartz porphyry.

The LB hosts seven orebodies north of the Qibaoshan quartz porphyry. These orebodies occur within the F2 Fault and along the unconformity separating the Hutian and Datang formations [28,45]. The LB is $1100 \mathrm{~m}$ long and extends to a depth $>200 \mathrm{~m}$ downdip (Figure 2b), with the largest individual orebody (I-1) being $758 \mathrm{~m}$ long and $<1$ to $177 \mathrm{~m}$ (average $16 \mathrm{~m}$ ) thick. Ore grades are $\leq 1.5 \mathrm{wt} \% \mathrm{Cu}$, $0.6-4.2 \mathrm{wt} \% \mathrm{Zn}$, and $0.2-0.9 \mathrm{wt} \% \mathrm{~Pb}$ [45].

East of the LB are the principal orebodies (e.g., VIII-20 and VIII-30) of the DB (Figure 2a,d), which are lenticular-type hosted by a limestone xenolith within quartz porphyry. The VIII-30 orebody occurs along the upper contact of the limestone xenolith and is 18-110 $\mathrm{m}$ long with an average thickness of $11.6 \mathrm{~m}$. The VIII-20 orebody occurs along the lower contact and is 105-425 m long (average $267 \mathrm{~m}$ ) with a thickness of $\sim 10 \mathrm{~m}$ (Figure 2a). The two orebodies contain 0.3 to $\sim 0.6 \mathrm{wt} \% \mathrm{Cu}$ and 13.0 to $\sim 24.0 \mathrm{wt} \% \mathrm{~S}$.

The JGB has a central position in the mine and is located southeast of the LB (Figure 2a). A total of 69 orebodies make up the JGB, with the largest explored being I-1 and III-3. The I-1 orebody is $500 \mathrm{~m}$ long, dips to the southwest at $40^{\circ}$ to $60^{\circ}$, and occurs at an unconformity between limestone and phyllite. Irregular lamellar and lenticular ores make up the III-3 orebody, which dips to the NE or SW at $45^{\circ}$ to $\sim 60^{\circ}$. This orebody trends $295^{\circ}$, is $350 \mathrm{~m}$ long, and occurs at the contact between the quartz porphyry and limestone (Figure 2c).

South of the DB is the JJB (Figure 2b), which consists mainly of the IX-1 orebody. This east-west trending orebody has an irregular, lamellar shape and dips to the south at $20^{\circ}$ to $\sim 80^{\circ}$. This $300 \mathrm{~m}$ long orebody thins with depth and contains 0.2 to $\sim 0.6 \mathrm{wt} \% \mathrm{Cu}$ and 13.4 to $\sim 16.4 \mathrm{wt} \% \mathrm{~S}$.

The $\mathrm{XB}$ consists of 16 orebodies, hosted by faults, and occurs in the eastern part of the mine. The largest orebody, I-3, trends $120^{\circ}$ and has a length of $820 \mathrm{~m}$ and width of 70 to $\sim 95 \mathrm{~m}$. It extends to a depth of $400 \mathrm{~m}$ and dips at $60^{\circ}$ to $\sim 75^{\circ}$.

\subsubsection{Ore Types and Mineral Paragenetic Sequence}

Ore minerals of the Qibaoshan deposit are dominantly magnetite, pyrite, chalcopyrite, sphalerite, and galena $[45,48,50]$. However, gangue minerals in the lenticular- and vein-type orebodies are different. Skarn minerals such as garnet, diopside, wollastonite, tremolite, actinolite, and 
pistacite are common gangue in lenticular-type orebodies, whereas quartz and calcite occur in the vein-type orebodies.

Six ore types are distinguished based on the content and assemblages of the main ore minerals. Type-one magnetite ores (Mt ores) are fine-grained magnetite (Figure 3a), locally replaced by chalcopyrite (Figure 4a), with rare tetradymite and joseite-B [51,52]. This ore type occurs mainly in the JJB and DB, in the middle of the deposit, and grades into magnetite-pyrite ore. Type-two magnetite-pyrite ores (Mt-Py ores) have a similar distribution to the Mag ores and consist of magnetite and pyrite (Figure 3b), with magnetite replaced by pyrite (Figure $4 b$ ). Type-three pyrite ores (Py ores) are massive and represent vein-type orebodies (Figure 3c). Pyrite crystals are euhedral to anhedral (Figure 4c) and up to $0.1 \mathrm{~mm}$ in size [28]. Type-four pyrite-sphalerite-galena-chalcopyrite ores (Py-Sp-Gn-Ccp ores) are widely distributed in the deposit and occur mainly as vein-type orebodies. The ore is massive (Figure 3d) below $-100 \mathrm{~m}$ sea level (s.l.) and poorly consolidated above this level due to the effects of groundwater. Pyrite is euhedral to subhedral, while other minerals are subhedral to anhedral. Arsenopyrite is a common mineral of type-four ores and is intergrown with sphalerite and pyrite. Type-five pyrite-chalcopyrite ores (Py-Ccp ores) occur in the LB as lenticular- and vein-type orebodies. Anhedral chalcopyrite $(0.1-0.6 \mathrm{~mm})$ and euhedral to subhedral pyrite are the ore minerals (Figure 3e), with trace pavonite (Figure 4d). Gangue minerals in lenticular orebodies are chlorite and forsterite (Figure 4e). The ore is poorly consolidated above $-100 \mathrm{~m}$ s.l., similar to the Py-Sp-Gn-Ccp ores. Type-six sphalerite-pyrite ores (Sp-Py ores) occur in the XB and consist mainly of subhedral to anhedral pyrite and sphalerite (Figure $4 \mathrm{f}$ ) ranging from 0.4 to $0.8 \mathrm{~mm}$ in size. Trace amounts of chalcopyrite with pyrrhotite occur as inclusions in pyrite (Figure 4g). Sphalerite showing chalcopyrite disease is common in the Sp-Py ores (Figure 4h). Arsenopyrite replaces pyrite, or occurs as euhedral crystals (Figure 4i), and is associated with a gangue of clay minerals and quartz. Type-six ores above $-100 \mathrm{~m}$ s.l. are poorly consolidated and have a cavernous texture (Figure 3f) due to the effects of groundwater.

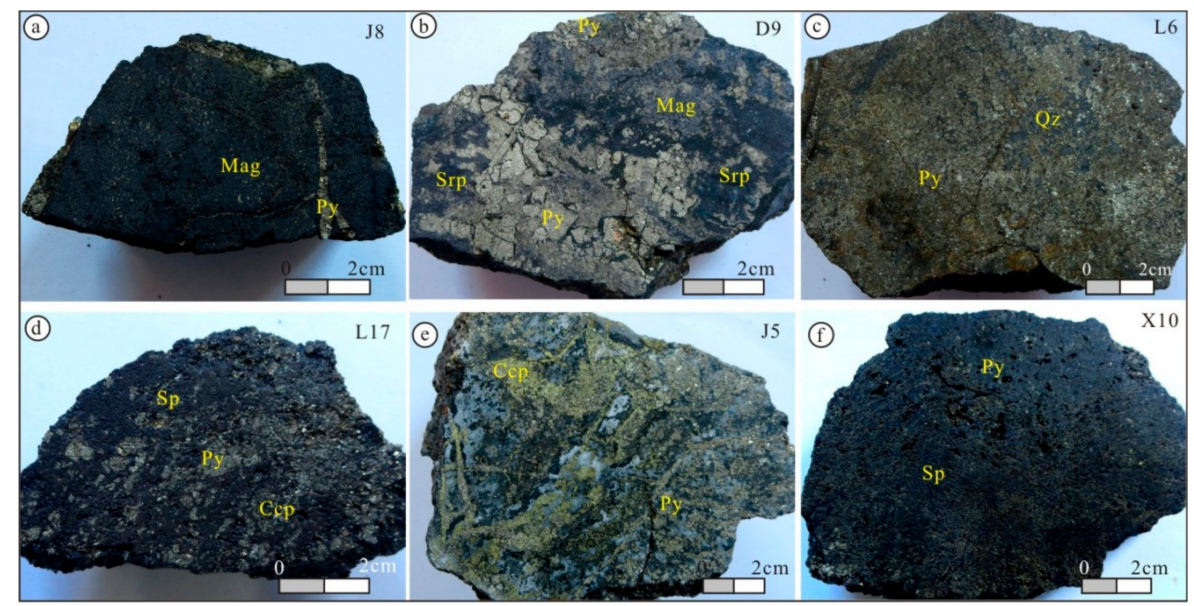

Figure 3. Representative specimens of ore types in the Qibaoshan deposit: (a) magnetite ore showing fine grained magnetite (Mag) cut by pyrite (Py) veins; (b) magnetite-pyrite ore with fillings of pyrite and serpentine (Srp); (c) pyrite ore with intergrowths of fine-grained pyrite and quartz (Qz); (d) pyrite-sphalerite-galena-chalcopyrite ore showing sphalerite around pyrite and chalcopyrite (Ccp); (e) pyrite-chalcopyrite ore with veins of pyrite and chalcopyrite cutting gangue minerals; and (f) sphalerite-pyrite ore showing cavernous texture.

Different stages of mineralization are documented for the Qibaoshan deposit (Figure 5) [28,53,54]. Initial skarn mineralization is subdivided into early, late, and oxide stages. Subsequent mineralization is separated into early and late quartz-sulfide stages, followed by supergene alteration. Significant In was deposited with sphalerite during the late quartz-sulfide stage. 

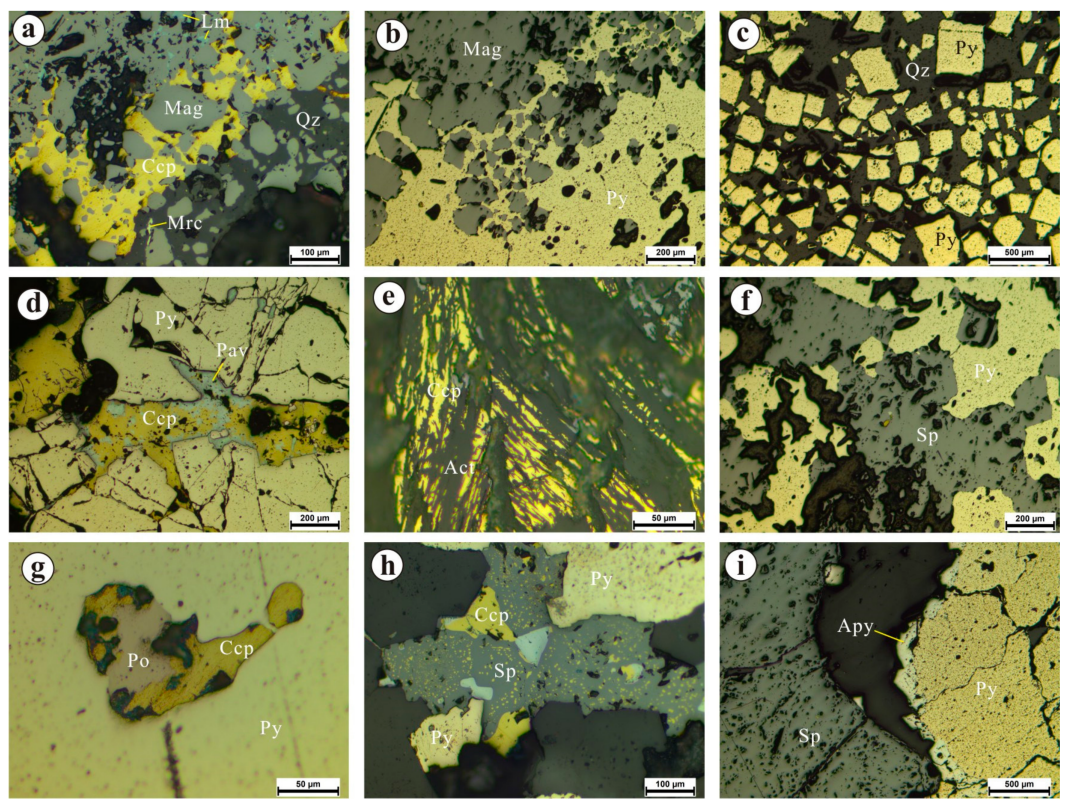

Figure 4. Photomicrographs showing minerals and textures in ores of the Qibaoshan deposit: (a) chalcopyrite (Ccp) replacing magnetite (Mag) with trace marcasite (Mrc) and limonite (Lm) in Mag ore; (b) pyrite (Py) replacing magnetite in Mag-Py ore; (c) euhedral pyrite in Py ore; (d) chalcopyrite with pavonite (Pav) filling pyrite in Py-Ccp ore; (e) chalcopyrite filling actinolite (Act) in Py-Ccp ore; (f) sphalerite replacing pyrite in Sp-Py ore; (g) pyrrhotite (Po) and chalcopyrite inclusions in pyrite of Sp-Py ore; (h) sphalerite with chalcopyrite disease in Sp-Py ore; and (i) arsenopyrite (Apy) replacing pyrite in Sp-Py ore.

\begin{tabular}{|c|c|c|c|c|c|c|}
\hline \multirow{2}{*}{$\overbrace{\text { Minerals }}^{\text {stages }}$} & \multicolumn{3}{|c|}{ Skarn } & \multicolumn{2}{|c|}{ Quartz-sulfide } & \multirow{2}{*}{ Supergene } \\
\hline & Early & Late & Oxide & Early & Late & \\
\hline \multicolumn{7}{|l|}{\begin{tabular}{|l|} 
Garnet \\
\end{tabular}} \\
\hline \multicolumn{7}{|l|}{ Diopside } \\
\hline \multicolumn{7}{|l|}{ Wollastonite } \\
\hline Tremolite & & - & & & & \\
\hline Actinolite & & $\longrightarrow$ & & & & \\
\hline \multicolumn{7}{|l|}{ Pistacite } \\
\hline \multicolumn{7}{|l|}{ Magnetite } \\
\hline Tetradymite & & & & - & & \\
\hline \multicolumn{7}{|l|}{ Pyrrhotite } \\
\hline \multicolumn{7}{|l|}{ Arsenopyrite } \\
\hline Marcasite & & & & - & & \\
\hline \multicolumn{7}{|l|}{ Pyrite } \\
\hline \multicolumn{7}{|l|}{ Chalcopyrite } \\
\hline Serpentine & & & - & - & & \\
\hline \multicolumn{7}{|l|}{ Chlorite } \\
\hline \multicolumn{7}{|l|}{ Quartz } \\
\hline Pavonite & & & & & - & \\
\hline \multicolumn{7}{|l|}{ Sphalerite } \\
\hline \multicolumn{7}{|l|}{ Galena } \\
\hline \multicolumn{7}{|l|}{ Dolomite } \\
\hline \multicolumn{7}{|l|}{ Calcite } \\
\hline Tennantite & & & & & - & \\
\hline Covellite & & & & & & - \\
\hline \multicolumn{7}{|l|}{ Limonite } \\
\hline Hematite & & & & & & - \\
\hline Psilomelane & & & & & & - \\
\hline Smithsonite & & & & & & - \\
\hline Malachite & & & & & & - \\
\hline
\end{tabular}

Figure 5. Paragenesis of mineralization in the Qibaoshan deposit (after [28]). 


\section{Sampling and Analyses}

\subsection{Sample Sites}

Orebodies in the JJB are deeper than those in the other blocks and have not been developed to date. Samples of ore were collected from underground workings of the LB, DB, XB, and JGB. The locations and types of samples are listed in Table 1.

Table 1. Location and descriptions of samples from the Qibaoshan deposit.

\begin{tabular}{|c|c|c|c|c|}
\hline \multicolumn{2}{|c|}{ Sample No } & Location & Ore Types & Description \\
\hline \multicolumn{5}{|c|}{ Laohukou Block (LB) } \\
\hline 1 & L1 & Level $40 \mathrm{~m}$ & Py-Ccp ores & Massive, coarse grained, Py > Ccp, Apy $(10 \%)$ \\
\hline 2 & L3 & Level $12 \mathrm{~m}$ & Py-Ccp ores & Loose sulfides, fine grained, $\mathrm{Py}>\mathrm{Sp}$ \\
\hline 3 & L6 & Level $12 \mathrm{~m}$ in No. 8-1 orebody & Py ores & Massive, medium-fine grained, $\mathrm{Py}(50 \%)>\mathrm{Ccp}(10 \%)$ \\
\hline 4 & L7 & Same as above & Py ores & Same as above \\
\hline 5 & L8 & Level $19 \mathrm{~m}$ in No. I orebody & Py-Sp-Gn-Ccp ores & Massive, medium-fine grained, $\mathrm{Py}(20 \%)>\mathrm{Sp}>\mathrm{Ccp}(5 \%)>\mathrm{Gn}$ \\
\hline 6 & L9 & Same as above & Py-Sp-Gn-Ccp ores & Loose sulfides, fine grained, $\mathrm{Py}>\mathrm{Sp}>\mathrm{C} c \mathrm{p}$ \\
\hline 7 & L10 & Same as above & Py-Ccp ores & Massive, medium-fine grained, $\mathrm{Sp}>\mathrm{Py}$ \\
\hline 8 & L12 & Same as above, & Py-Sp-Gn-Ccp ores & Massive, medium-fine grained, $\mathrm{Sp}(30 \%)>\mathrm{Py}>\mathrm{Ccp}>\mathrm{Gn}$ \\
\hline 9 & L14 & Level $12 \mathrm{~m}$ in No. I orebody & Py-Cсp ores & Massive, medium-fine grained, $\mathrm{Py}>\mathrm{Ccp}$ \\
\hline 10 & L17 & Same as above & Py-Sp-Gn-Ccp ores & Disseminated, medium-fine grained, $\mathrm{Sp}>\mathrm{Py}>\mathrm{Ccp}>\mathrm{Gn}$ \\
\hline \multicolumn{5}{|c|}{ Daqibaoshan Block (DB) } \\
\hline 11 & D9 & Level $116 \mathrm{~m}$ & Mag-Py ores & Massive, coarse grained, $\mathrm{Py}>\mathrm{Mag}(10 \%)$, contained serpentine \\
\hline 12 & D16 & Same as above & Mag-Py ores & Massive, coarse grained, $\mathrm{Mag}>\mathrm{Py}>\mathrm{Sp}$ \\
\hline \multicolumn{5}{|c|}{ Xiaoqibaoshan Block (XB) } \\
\hline 13 & $\mathrm{X} 1$ & Level-29 m@ line 52 & Py-Ccp ores & Disseminated, medium-fine grained, $\mathrm{Py}>\mathrm{Ccp}>\mathrm{Sp}$ \\
\hline 14 & X6 & Level-43 m @ line 58 & Sp-Py ores & Disseminated, medium-fine grained, $\mathrm{Py}>\mathrm{Sp}$ \\
\hline 15 & $\mathrm{X} 7$ & Level-43 m @ line 68 & Sp-Py ores & Disseminated, medium-fine grained, $\mathrm{Sp}>\mathrm{Py}$ \\
\hline 16 & $\mathrm{X} 8$ & Same as above & Sp-Py ores & Disseminated, medium-fine grained, $\mathrm{Py}>\mathrm{Sp}$ \\
\hline 17 & X9 & Same as above & Sp-Py ores & Disseminated, medium-fine grained, $\mathrm{Sp}>\mathrm{Py}$ \\
\hline 18 & $\mathrm{X} 10$ & Same as above & Sp-Py ores & Same as above \\
\hline 19 & $\mathrm{X} 11$ & Level -43 m @ line 70 & Sp-Py ores & Same as above \\
\hline 20 & $\mathrm{X} 12$ & Level-45 m @ line 62 & Sp-Py ores & Same as above \\
\hline 21 & $\mathrm{X} 13$ & Level -43 m @ line 58 & Py-Ccp ores & Disseminated, medium-fine grained, $\mathrm{Sp}>\mathrm{Py}$ \\
\hline \multicolumn{5}{|c|}{ Jigongwan Block (JGB) } \\
\hline 22 & $\mathrm{~J} 5$ & Level $84 \mathrm{~m}$ & Py-Ccp ores & Disseminated, medium-fine grained, $\mathrm{Py}>\mathrm{Ccp}$ \\
\hline 23 & $\mathrm{~J} 8$ & Same as above & Mag ores & Disseminated, medium-fine grained, Mag $>$ Py \\
\hline
\end{tabular}

\subsection{Whole-Rock Geochemical Analyses}

Twenty-three representative ores samples from the LB, DB, XB, and JGB of the Qibaoshan deposit were analyzed at Australia Laboratory Services (ALS), ALS Chemex in Guangzhou, China. Bulk samples were processed using perchloric, nitric, hydrofluoric, and hydrochloric acids (four acids), digested, and then In contents were measured using inductively coupled plasma-mass spectrometry (ICP-MS), with detection limits of 0.005 to $500 \mathrm{ppm}$. Other elements, including P, S, V, Cr, Mn, Fe, Co, $\mathrm{Ni}, \mathrm{Cu}, \mathrm{Zn}, \mathrm{As}, \mathrm{Ag}, \mathrm{Cd}, \mathrm{Sn}, \mathrm{Sb}, \mathrm{W}, \mathrm{Pb}$, and $\mathrm{Bi}$, were processed with four acids and sodium peroxide flux, and analyzed using inductively coupled plasma-atomic emission spectroscopy (ICP-AES).

\subsection{Electron-Probe Microanalyses}

Minerals were identified in polished thick sections using standard reflected-light microscopy techniques. The results of bulk-rock geochemistry were used to select In-rich samples for detailed mineralogical and in situ compositional studies. Electron-probe microanalysis (EPMA) were conducted using a Shimadzu EPMA-1720H electron microprobe housed at the School of Geosciences and Info-physics, Central South University, Changsha, China. Operating conditions of the electron microprobe were a $15 \mathrm{kV}$ accelerating voltage, $10 \mathrm{nA}$ beam current, and $1 \mu \mathrm{m}$ diameter electron beam. The X-ray lines used to analyze different elements were as follows: $\mathrm{S}(K \alpha), \mathrm{Mn}(K \alpha), \mathrm{Fe}(K \alpha), \mathrm{Zn}$ $(K \alpha), \mathrm{Ge}(L \alpha), \mathrm{Se}(L \alpha), \mathrm{Cd}(L \alpha)$, In $(L \alpha)$, and $S n(L \alpha)$. Mineral and metal standards used for elemental calibration included pyrite (S and Fe), metallic Mn (Mn), sphalerite ( $\mathrm{Zn}$ ), germanium sulfide (Ge), bismuth selenide (Se), greenockite (Cd), indium antimonide (In), and herzenbergite (Sn). The resulting data were then ZAF corrected using proprietary Shimadzu software. 


\section{Indium Contents of Ores and Mineral Chemistry}

\subsection{Chemical Composition of Ores and Element Correlations}

The results of chemical analyses of 23 samples from the Sp-Py, Py-Ccp, Py-Sp-Gn-Ccp, Py, Mag-Py, and Mag ores are listed in Table 2. Samples of Sp-Py ores contain 9.8-22.2 wt \% Zn, 0.2-0.3 wt \% Cu, 28.9-203.0 ppm (average 122.8 ppm) In, and $1000 \mathrm{In} / \mathrm{Zn}$ values of 2.6-8.8 (average 7.4). Samples of Py-Ccp ores contain 1.3-10.3 wt \% Cu, 0.6-0.9 wt \% Zn, 4.1-42.7 ppm (average 16.8 ppm) In, and $1000 \mathrm{In} / \mathrm{Zn}$ values of 5.8-74.9 (average 25.5). Samples of Py-Sp-Gn-Ccp ores contain 0.5-2.0 wt \% Cu, 0.9-17.5 wt \% Zn, 0.3-5.3 wt \% Pb, 3.6-19.0 ppm (average $11.5 \mathrm{ppm}$ ) In, and $1000 \mathrm{In} / \mathrm{Zn}$ values of 1.1-8.4 (average 3.3). Differences between the ore types include lower grades of $\mathrm{Cu}, \mathrm{Zn}$, and In, and higher $1000 \mathrm{In} / \mathrm{Zn}$ ratios in the Py, Mag-Py, and Mag ores. Specifically, the average In contents of the Py, Mag-Py, and Mag ores are 6.6, 81.5, and 12.0 ppm, and the $1000 \mathrm{In} / \mathrm{Zn}$ values are 93.6, 33.7, and 185.0 , respectively.

Table 2. Geochemical data for ore types of the Qibaoshan deposit.

\begin{tabular}{|c|c|c|c|c|c|c|c|c|c|c|c|c|c|c|c|c|c|c|c|c|}
\hline $\begin{array}{c}\text { Units } \\
\text { Detection limits } \\
\end{array}$ & $1000 \mathrm{In} / \mathrm{Zn}$ & $\begin{array}{c}\text { In } \\
\text { ppm } \\
0.005\end{array}$ & $\begin{array}{c}\text { Sn } \\
\text { ppm } \\
10\end{array}$ & $\begin{array}{c}\mathrm{Cd} \\
\mathrm{ppm} \\
0.5\end{array}$ & $\begin{array}{c}\mathrm{Zn} \\
\mathrm{wt} \% \\
2\end{array}$ & $\begin{array}{c}\mathrm{Pb} \\
\mathrm{ppm} \\
2\end{array}$ & $\begin{array}{c}\mathrm{Cu} \\
\mathrm{wt} \% \\
0.01\end{array}$ & $\begin{array}{c}\mathrm{Fe} \\
\mathrm{wt} \% \\
0.1\end{array}$ & $\begin{array}{c}\text { Mn } \\
\text { ppm } \\
0.01\end{array}$ & $\begin{array}{c}\mathrm{Ni} \\
\text { ppm } \\
1\end{array}$ & $\begin{array}{c}\text { Co } \\
\text { ppm } \\
1\end{array}$ & $\begin{array}{c}\mathrm{W} \\
\text { ppm } \\
10\end{array}$ & $\begin{array}{c}\mathbf{B i} \\
\text { ppm } \\
2\end{array}$ & $\begin{array}{c}\text { As } \\
\text { ppm } \\
5\end{array}$ & $\begin{array}{c}\text { Sb } \\
\text { ppm } \\
5\end{array}$ & $\begin{array}{c}\mathrm{Ag} \\
\text { ppm } \\
0.5\end{array}$ & $\begin{array}{c}\mathrm{Cr} \\
\text { ppm } \\
1\end{array}$ & $\begin{array}{c}\text { P } \\
\text { ppm } \\
10\end{array}$ & $\begin{array}{c}\mathrm{V} \\
\text { ppm } \\
1\end{array}$ & $\begin{array}{c}\mathrm{S} \\
\text { wt } \% \\
0.1 \\
\end{array}$ \\
\hline \multicolumn{21}{|l|}{ Sp-Py ores } \\
\hline X6 & 2.63 & 28.9 & 30 & 351 & 11.00 & 16,100 & 0.15 & 35 & 501 & 1 & $<1$ & 10 & 35 & 2920 & 115 & 35.4 & 12 & 10 & 5 & 45.7 \\
\hline $\mathrm{X} 7$ & 7.48 & 135 & 50 & 535 & 18.05 & 2720 & 0.32 & 31.2 & 949 & 1 & $<1$ & 40 & 59 & 1520 & 81 & 48.2 & 9 & 40 & 4 & 43.4 \\
\hline $\mathrm{X} 8$ & 7.12 & 121 & 20 & 497 & 17.00 & 494 & 0.27 & 25.4 & 799 & 12 & 4 & 10 & 81 & 603 & 72 & 34 & 19 & 50 & 7 & 36.2 \\
\hline X9 & 7.66 & 170 & 10 & 622 & 22.20 & 105 & 0.18 & 25.6 & 801 & 61 & 50 & $<10$ & 20 & 255 & 105 & 9.1 & 7 & 20 & 2 & 38 \\
\hline $\mathrm{X} 10$ & 5.84 & 121.5 & 10 & 563 & 20.80 & 313 & 0.2 & 27.2 & 863 & 41 & 36 & 30 & 69 & 197 & 21 & 17.3 & 5 & 20 & 1 & 39.6 \\
\hline $\mathrm{X} 11$ & 10.89 & 106.5 & 30 & 315 & 9.78 & 6330 & 0.23 & 36.1 & 491 & 3 & 7 & 20 & 375 & 11,200 & 158 & $>100$ & 7 & 20 & 3 & 45.6 \\
\hline $\mathrm{X} 12$ & 4.78 & 96.5 & 10 & 711 & 20.20 & 186 & 0.23 & 32.1 & 643 & 21 & 14 & 30 & 244 & 586 & 129 & 23.4 & 12 & 20 & 4 & 44.8 \\
\hline L10 & 9.95 & 203 & 20 & 645 & 20.40 & 890 & 0.32 & 32 & 2730 & $<1$ & $<1$ & 10 & 85 & 750 & 50 & 38.1 & 10 & 10 & 3 & 44.8 \\
\hline Mean $(n=8)$ & 7.04 & 122.8 & 23 & 530 & 17.43 & 3392 & 0.24 & 30.6 & 972 & 18 & 14 & 19 & 121 & 2254 & 91 & 38.2 & 10 & 24 & 4 & 42.3 \\
\hline \multicolumn{21}{|l|}{$P y$-Ccp ores } \\
\hline $\mathrm{x} 13$ & 11.51 & 8.52 & 120 & 4.3 & 0.74 & 290 & 1.3 & 31.7 & $<5$ & 3 & 1 & 10 & 268 & 1100 & 30 & 72.2 & 9 & 20 & 3 & 36.9 \\
\hline $\mathrm{X} 1$ & 5.84 & 4.09 & 30 & $<0.5$ & 0.7 & 16 & 1.15 & 32.7 & 41 & 10 & $<1$ & $<10$ & 896 & 130 & 400 & 24.9 & 19 & 70 & 10 & 37.5 \\
\hline L1 & 74.91 & 42.7 & 150 & 13.7 & 0.57 & 287 & 10.25 & 39.7 & 34 & 25 & 24 & $<10$ & 2690 & 1320 & 59 & $>100$ & 9 & 10 & 4 & 46.5 \\
\hline L3 & 14.68 & 13.65 & 40 & 24.4 & 0.93 & 1140 & 2.24 & 38.3 & 90 & 16 & 18 & $<10$ & 586 & 2350 & 103 & 80.5 & 15 & 40 & 16 & 44.7 \\
\hline L14 & 20.75 & 15.15 & 70 & 10.6 & 0.73 & 398 & 6.69 & 41.8 & 29 & 14 & 22 & $<10$ & 353 & 729 & 28 & $>100$ & 9 & 10 & 3 & 48.8 \\
\hline Mean $(n=5)$ & 25.54 & 16.82 & 82 & 10.6 & 0.73 & 426 & 4.33 & 36.8 & 39 & 14 & 13 & 10 & 959 & 1126 & 124 & 75.5 & 12 & 30 & 7 & 42.9 \\
\hline \multicolumn{21}{|c|}{$P y-S p-G n$-Ccp ores } \\
\hline L8 & 2.21 & 3.61 & 30 & 13.7 & 1.63 & 2930 & 1.68 & 43 & 43 & 1 & 9 & $<10$ & 410 & 368 & 49 & $>100$ & 13 & 220 & 8 & 50.5 \\
\hline L9 & 8.36 & 7.61 & 20 & 29.2 & 0.91 & 2500 & 0.51 & 30.5 & 90 & 10 & 8 & 10 & 208 & 394 & 16 & 34.6 & 22 & 140 & 24 & 35.4 \\
\hline L12 & 1.48 & 15.7 & 60 & 303 & 10.6 & 34,300 & 1.53 & 34.9 & 752 & 5 & 3 & 50 & 901 & 1810 & 66 & $>100$ & 14 & 10 & 3 & 45.6 \\
\hline L17 & 1.09 & 18.95 & 90 & 634 & 17.45 & 52,600 & 1.96 & 30.5 & 1340 & 3 & $<1$ & 40 & 464 & 1230 & 98 & $>100$ & 18 & 20 & 4 & 43.7 \\
\hline Mean $(n=4)$ & 3.29 & 11.47 & 50 & 245.0 & 7.65 & 23,083 & 1.42 & 34.7 & 556 & 5 & 5 & 28 & 496 & 951 & 57 & 84.7 & 17 & 98 & 10 & 43.8 \\
\hline \multicolumn{21}{|l|}{ Py ores } \\
\hline L6 & 21.52 & 4.95 & 10 & 13.5 & 0.23 & 155 & 0.23 & 41.1 & 649 & 1 & 35 & $<10$ & 100 & 204 & $<5$ & 15 & 8 & $<10$ & 13 & 41.3 \\
\hline L7 & & 8.28 & 30 & 3.3 & 0.05 & 91 & 0.56 & 39.9 & 673 & 2 & 17 & 10 & 182 & 89 & $<5$ & 24.9 & 13 & 30 & 22 & 39.1 \\
\hline Mean $(n=2)$ & 93.56 & 6.62 & 20 & 8.4 & 0.14 & 123 & 0.40 & 40.5 & 661 & 1 & 26 & 10 & 141 & 147 & $<5$ & 20.0 & 11 & 20 & 18 & 40.2 \\
\hline \multicolumn{21}{|l|}{ Mag-Py ores } \\
\hline D9 & 52.25 & 1.05 & 30 & 0.9 & 0.02 & 37 & 0.19 & 41.8 & 208 & 4 & 3 & 1130 & 35 & 45 & $<5$ & 4 & 7 & 70 & 23 & 33.1 \\
\hline D16 & 15.07 & 162 & 20 & 340 & 10.75 & 38 & 0.49 & 35.6 & 196 & 1 & $<1$ & 40 & 57 & 40 & $<5$ & 8.2 & 20 & 80 & 12 & 33.8 \\
\hline Mean $(n=2)$ & 33.66 & 81.53 & 25 & 170.5 & 5.39 & 38 & 0.34 & 38.7 & 202 & 3 & 2 & 585 & 46 & 43 & $<5$ & 6.1 & 14 & 75 & 188 & 33.5 \\
\hline \multicolumn{21}{|l|}{ Mag ores } \\
\hline $\mathrm{J} 5$ & 324.29 & 22.7 & 40 & 5.5 & 0.07 & 71 & 2.06 & 24 & 1330 & 30 & 69 & 60 & 29 & 62 & $<5$ & 43.3 & 40 & 320 & 63 & 24.7 \\
\hline $\mathrm{J} 8$ & 45.67 & 1.37 & 10 & 2.1 & 0.03 & 8 & 0.43 & 61.6 & 801 & 6 & 45 & 30 & 18 & 6 & $<5$ & 8.9 & 13 & 40 & 52 & 5.8 \\
\hline Mean $(n=2)$ & 184.98 & 12.04 & 25 & 3.8 & 0.05 & 40 & 1.25 & 42.8 & 1066 & 18 & 57 & 45 & 24 & 34 & $<5$ & 26.1 & 26.50 & 180 & 58 & 15.3 \\
\hline
\end{tabular}

Based on the results of cluster analysis (Figure 6), element correlations in the Qibaoshan ores are divided into three groups. The first group contains the elements $\mathrm{Zn}, \mathrm{Cd}, \mathrm{In}, \mathrm{Fe}, \mathrm{Mn}, \mathrm{Ni}$, and Sb. Indium and $\mathrm{Cd}$ are strongly correlated with $\mathrm{Zn}$, indicating In and $\mathrm{Cd}$ are hosted mainly by sphalerite. Some samples (e.g., L1) with high In/Zn ratios and $\mathrm{Cu}$ concentrations may indicate that chalcopyrite hosts In, similar to the Yejiwei deposit and In-rich deposits in SW England [55,56]. The second group contains the elements $\mathrm{Cu}, \mathrm{Bi}, \mathrm{Sn}$, and $\mathrm{Pb}$, of which $\mathrm{Cu}$ and $\mathrm{Bi}$ are strongly correlated. The third group contains the elements S, V, Cr, P, As, V and S. Correlation coefficients for the major elements in ores are listed in Table 3. The highest correlation coefficient (0.99) is between $\mathrm{Cd}$ and $\mathrm{Zn}$. Notable correlation coefficients also exist for In and $\mathrm{Zn}(0.81), \mathrm{Cu}$ and Bi (0.81), S and V (0.80), Cd and In (0.77), Cr and $\mathrm{P}(0.76)$, and $\mathrm{Sn}$ and $\mathrm{Cu}(0.76)$. Correlations are weaker between In and the following elements: Mn (0.52), Fe (0.45), and V (0.38). In addition, the weak correlation between In and Sn (0.12), and high arsenic content of In-rich ores are similar to the Toyoha mine [57]. 


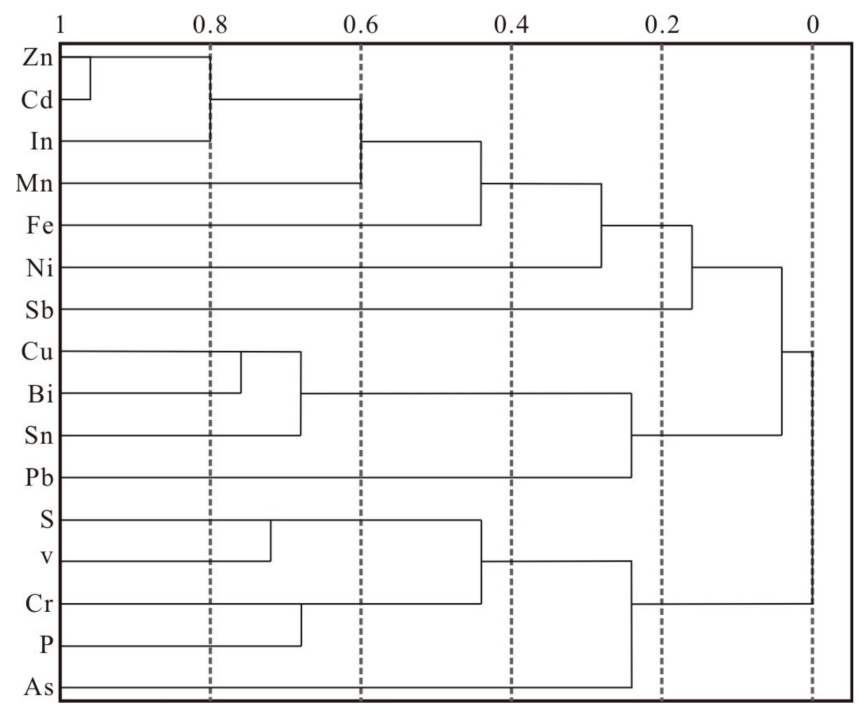

Figure 6. R-type cluster analysis dendrogram of elements in the Qibaoshan deposit.

Table 3. Correlation coefficients for select elements in ores of the Qibaoshan deposit.

\begin{tabular}{ccccccccccccccccc}
\hline & $\mathbf{Z n}$ & $\mathbf{C u}$ & $\mathbf{F e}$ & $\mathbf{S}$ & $\mathbf{I n}$ & $\mathbf{A s}$ & $\mathbf{B i}$ & $\mathbf{C d}$ & $\mathbf{C r}$ & $\mathbf{M n}$ & $\mathbf{N i}$ & $\mathbf{P}$ & $\mathbf{P b}$ & $\mathbf{S b}$ & $\mathbf{S n}$ & $\mathbf{V}$ \\
\hline $\mathrm{Zn}$ & 1.00 & & & & & & & & & & & & & & & \\
$\mathrm{Cu}$ & 0.35 & 1.00 & & & & & & & & & & & & & \\
$\mathrm{Fe}$ & 0.54 & 0.17 & 1.00 & & & & & & & & & & & & \\
$\mathrm{~S}$ & 0.25 & 0.27 & 0.33 & 1.00 & & & & & & & & & & & \\
$\mathrm{In}$ & 0.81 & 0.25 & 0.45 & 0.13 & 1.00 & & & & & & & & & & \\
$\mathrm{As}$ & 0.09 & 0.04 & 0.01 & 0.30 & 0.12 & 1.00 & & & & & & & & & \\
$\mathrm{Bi}$ & 0.26 & 0.81 & 0.11 & 0.32 & 0.22 & 0.10 & 1.00 & & & & & & & & \\
$\mathrm{Cd}$ & 0.99 & 0.35 & 0.52 & 0.26 & 0.77 & 0.10 & 0.25 & 1.00 & & & & & & & \\
$\mathrm{Cr}$ & 0.23 & 0.03 & 0.30 & 0.37 & 0.20 & 0.23 & 0.09 & 0.20 & 1.00 & & & & & & \\
$\mathrm{Mn}$ & 0.57 & 0.30 & 0.27 & 0.09 & 0.52 & 0.05 & 0.31 & 0.59 & 0.11 & 1.00 & & & & & \\
$\mathrm{Ni}$ & 0.31 & 0.16 & 0.41 & 0.08 & 0.30 & 0.18 & 0.09 & 0.25 & 0.01 & 0.02 & 1.00 & & & & \\
$\mathrm{P}$ & 0.34 & 0.05 & 0.16 & 0.28 & 0.22 & 0.21 & 0.15 & 0.35 & 0.76 & 0.04 & 0.08 & 1.00 & & & & \\
$\mathrm{~Pb}$ & 0.26 & 0.00 & 0.12 & 0.24 & 0.19 & 0.16 & 0.12 & 0.32 & 0.09 & 0.23 & 0.23 & 0.18 & 1.00 & & & \\
$\mathrm{Sb}$ & 0.13 & 0.05 & 0.22 & 0.24 & 0.02 & 0.27 & 0.25 & 0.13 & 0.00 & 0.14 & 0.05 & 0.15 & 0.10 & 1.00 & \\
$\mathrm{Sn}$ & 0.26 & 0.76 & 0.01 & 0.27 & 0.29 & 0.07 & 0.71 & 0.24 & 0.06 & 0.24 & 0.08 & 0.15 & 0.29 & 0.02 & 1.00 & \\
$\mathrm{~V}$ & 0.51 & 0.10 & 0.30 & 0.80 & 0.38 & 0.25 & 0.23 & 0.49 & 0.65 & 0.08 & 0.02 & 0.64 & 0.22 & 0.32 & 0.22 & 1.00 \\
\hline
\end{tabular}

Binary diagrams incorporating data for major elements highlight differences between the ore types. Data for In and Sn define In/Sn values of 0.01-10 (Figure 7a) and have a correlation coefficient of 0.29 . The highest In/Sn values of 1-10 are obtained for Sp-Py ores (Figure 7a). Values of In/Cu are 0.0001-0.1 (Figure 7b), with a correlation coefficient of 0.25. The lowest $\mathrm{In} / \mathrm{Cu}$ values are for Sp-Py ores. Values of In/Zn span a range of 0.0001 to 0.1 (Figure 7c). Data for Sp-Py ores plot in a tight cluster around $\mathrm{In} / \mathrm{Zn}$ values of 0.001 (Figure $7 \mathrm{c}$ ). Zinc and cadmium have the highest correlation coefficient (0.99) and $\mathrm{Cd} / \mathrm{Zn}$ values range from 0.0005 to 0.05 (Figure $7 \mathrm{~d}$ ). 
$\diamond$ Sp-Py ores $\square$ Ccp-Py ores $\Delta$ Gn-Ccp-Sp-Py ores $\Delta$ Py ores $\bigcirc$ Mag-Py ores $O$ Mag ores
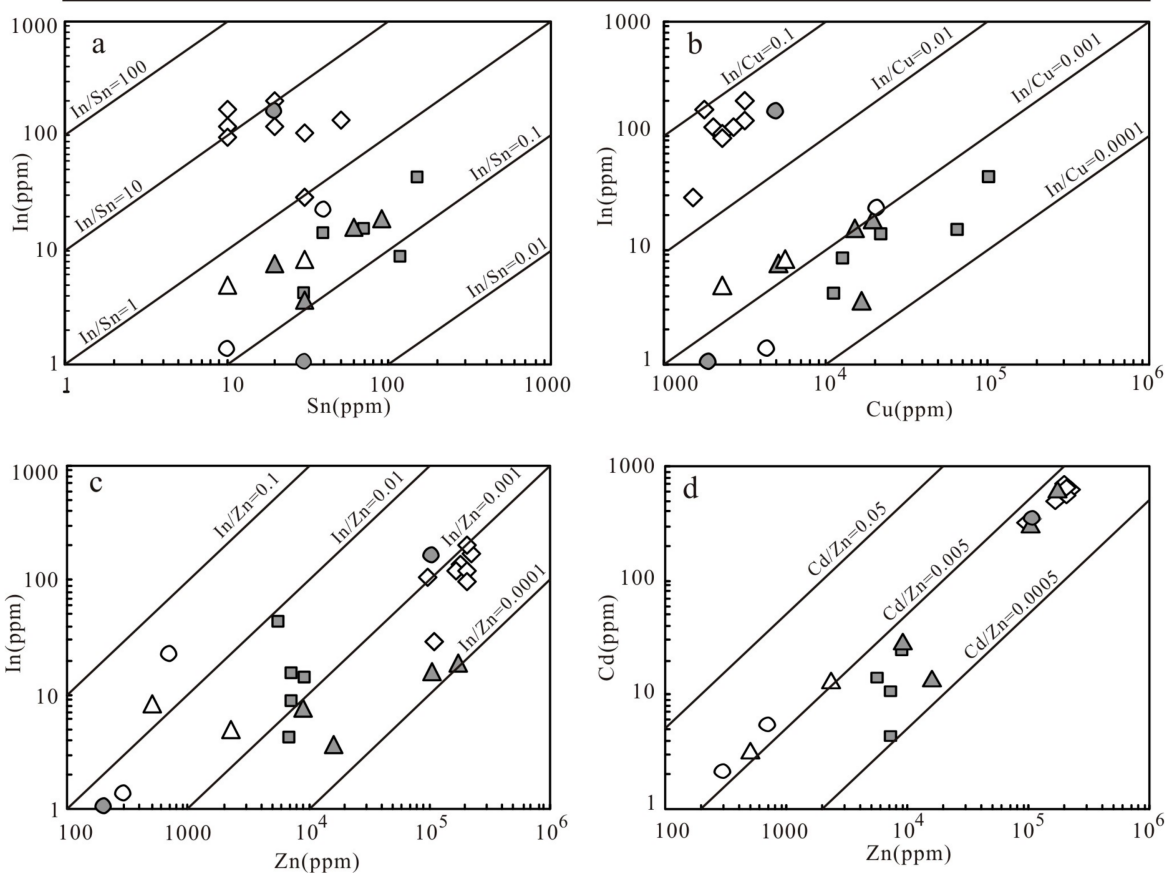

Figure 7. (a) In-Sn; (b) In-Cu; (c) In-Zn; and (d) Cd-Zn binary diagrams for the Qibaoshan deposit.

\subsection{Chemistry of Sphalerite}

Indium is closely associated with sphalerite in ore deposits, which serves as an important relationship for exploration. Geochemical data for the Qibaoshan deposit (Table 2) indicate a positive correlation between In grade and Zn concentrations in ores. Sphalerite in samples of Sp-Py ores was analyzed by EPMA, together with two samples of Mag ores and Py-Ccp ores (Table 4). Sphalerite contains 51.8 to $\sim 56.8 \mathrm{wt} \% \mathrm{Zn}, 8.7$ to $\sim 12.2 \mathrm{wt} \% \mathrm{Fe}$ (average $11.2 \mathrm{wt} \%$ ), 31.3 to $\sim 35.4 \mathrm{wt} \% \mathrm{~S}$ (average $33.8 \mathrm{wt} \%)$, and trace amounts of $\mathrm{Mn}(0.1$ to $\sim 0.7 \mathrm{wt} \%)$ and Cd (0.1 to $\sim 0.4 \mathrm{wt} \%$; average $0.16 \mathrm{wt} \%)$. More than half of the spot analyses detected In, with concentrations up to $0.1 \mathrm{wt} \%$. These data show how sphalerite in the Qibaoshan deposit contains low concentrations of $\mathrm{Cd}$, in contrast to the sphalerite in Sn-rich deposits such as Dulong (average $0.2 \mathrm{wt} \% \mathrm{Cd}$ ), Toyoha (average $0.4 \mathrm{wt} \% \mathrm{Cd}$ ), Dachang (average $0.4 \mathrm{wt} \% \mathrm{Cd}$ ), and Bolivar (average $0.8 \mathrm{wt} \% \mathrm{Cd}$; [58]).

Table 4. EPMA data for sphalerite from the Qibaoshan deposit (wt \%).

\begin{tabular}{ccccccccccc}
\hline Sample Nos & Zn & Fe & Mn & Cd & Sn & In & Ge & S & Se & Total \\
\hline X6-sp01 & 51.75 & 11.54 & 0.21 & 0.13 & 0.00 & 0.00 & 0.00 & 35.37 & 0.00 & 98.99 \\
X6-sp02 & 52.35 & 11.73 & 0.17 & 0.21 & 0.00 & 0.04 & 0.00 & 34.91 & 0.01 & 99.42 \\
X6-sp03 & 53.34 & 11.79 & 0.13 & 0.18 & 0.00 & 0.07 & 0.04 & 34.03 & 0.00 & 99.57 \\
X7-sp01 & 52.22 & 11.78 & 0.33 & 0.17 & 0.00 & 0.06 & 0.01 & 34.19 & 0.02 & 98.77 \\
X7-sp02 & 53.03 & 11.91 & 0.18 & 0.19 & 0.00 & 0.06 & 0.00 & 34.44 & 0.02 & 99.82 \\
X7-sp03 & 53.90 & 10.95 & 0.33 & 0.13 & 0.00 & 0.06 & 0.01 & 33.63 & 0.00 & 99.00 \\
X7-sp04 & 52.42 & 11.51 & 0.45 & 0.15 & 0.00 & 0.04 & 0.00 & 34.30 & 0.00 & 98.86 \\
X7-sp05 & 54.51 & 11.46 & 0.31 & 0.16 & 0.00 & 0.02 & 0.00 & 34.00 & 0.00 & 100.47 \\
X7-sp06 & 52.78 & 11.16 & 0.40 & 0.16 & 0.00 & 0.10 & 0.02 & 34.02 & 0.00 & 98.63 \\
X8-sp01 & 52.98 & 11.54 & 0.32 & 0.13 & 0.00 & 0.00 & 0.02 & 34.44 & 0.00 & 99.43 \\
X8-sp02 & 53.74 & 11.61 & 0.31 & 0.16 & 0.00 & 0.00 & 0.00 & 34.04 & 0.00 & 99.85 \\
X8-sp03 & 52.27 & 11.86 & 0.20 & 0.19 & 0.00 & 0.07 & 0.00 & 34.24 & 0.01 & 98.84 \\
X10-sp01 & 53.97 & 11.60 & 0.17 & 0.16 & 0.00 & 0.00 & 0.02 & 34.21 & 0.00 & 100.14 \\
\hline
\end{tabular}


Table 4. Cont.

\begin{tabular}{ccccccccccc}
\hline Sample Nos & Zn & Fe & Mn & Cd & Sn & In & Ge & S & Se & Total \\
\hline X10-sp03 & 52.41 & 12.23 & 0.23 & 0.15 & 0.00 & 0.09 & 0.02 & 34.08 & 0.00 & 99.20 \\
X11-sp02 & 53.19 & 11.24 & 0.14 & 0.17 & 0.00 & 0.02 & 0.00 & 34.71 & 0.03 & 99.51 \\
X11-sp03 & 54.09 & 10.34 & 0.66 & 0.17 & 0.00 & 0.04 & 0.00 & 34.29 & 0.00 & 99.59 \\
X11-sp04 & 53.47 & 11.11 & 0.18 & 0.12 & 0.04 & 0.01 & 0.02 & 34.32 & 0.00 & 99.28 \\
X11-sp05 & 53.84 & 11.37 & 0.16 & 0.18 & 0.00 & 0.00 & 0.00 & 33.54 & 0.00 & 99.09 \\
X12-sp02 & 53.41 & 11.03 & 0.21 & 0.17 & 0.02 & 0.05 & 0.00 & 34.19 & 0.00 & 99.09 \\
L10-sp01 & 56.10 & 11.55 & 0.32 & 0.12 & 0.00 & 0.00 & 0.00 & 33.57 & 0.00 & 101.66 \\
L10-sp02 & 53.69 & 12.07 & 0.36 & 0.12 & 0.00 & 0.00 & 0.00 & 33.07 & 0.00 & 99.31 \\
L10-sp05 & 53.31 & 11.52 & 0.34 & 0.12 & 0.00 & 0.00 & 0.00 & 33.61 & 0.00 & 98.90 \\
L10-sp06 & 55.76 & 11.46 & 0.30 & 0.08 & 0.00 & 0.00 & 0.00 & 33.84 & 0.00 & 101.44 \\
L14-sp02 & 56.00 & 8.78 & 0.64 & 0.21 & 0.00 & 0.00 & 0.00 & 32.89 & 0.00 & 98.51 \\
J7-sp06 & 54.73 & 11.57 & 0.25 & 0.34 & 0.00 & 0.00 & 0.00 & 33.60 & 0.00 & 100.50 \\
\hline
\end{tabular}

\section{Discussion}

\subsection{Correlation of Indium with Other Elements}

The correlation coefficients determined for six ore types in the Qibaoshan deposit indicate In is strongly correlated with Cd and Zn (Table 3), but poorly correlated with Sn. Cluster analysis also indicates In, Cd, and $\mathrm{Zn}$ belong to the same element group (Figure 6). In/Sn values for the Qibaoshan deposit are greater than for Bolivian Sn-rich In deposits [8] and for the Dachang and Dulong Sn-rich In deposits [6]. Geochemical data for the Qibaoshan deposit indicate the ores are Sn poor, and electron microprobe and reflected-light petrographic studies did not identify any Sn minerals. Therefore, Sn was not an important component of the ore-forming fluids. The formation of the In-rich and Sn-poor Qibaoshan deposit did not involve simultaneous enrichment and depletion of these two elements, as has been reported for ore fluids forming both In-rich and In-poor deposits [59]. Excluding $\mathrm{Sn}$, In has similar geochemical properties to base metal groups I-B ( Cu, Ag), II-B ( $\mathrm{Zn}, \mathrm{Cd}), \mathrm{IV}-\mathrm{A}(\mathrm{Pb})$, and V-A (Bi) in the Periodic Table. As In strongly correlates with $\mathrm{Cd}$ and $\mathrm{Zn}$ in the Qibaoshan deposit, these elements are inferred to behave similarly during magmatic and ore-forming processes in a Sn-poor environment.

\subsection{Indium Distribution in the Qibaoshan Deposit}

The distribution of In can vary significantly within a deposit. At the Mount Pleasant mine (Fredericton, NB, Canada), In-bearing orebodies are best developed in the Upper Deep Tin Zone [60]. In contrast, skarn ores of the No. 31 and No. 32 orebodies dominantly host In at the Yejiwei deposit, Hunan province, China (Figure 1a) [55]. Important ore zones at the Qibaoshan deposit occur in the LB and XB, which contain Type- $6 \mathrm{Sp}$-Py ores in vein-type orebodies. As bulk geochemical data indicate In grades are highest for Sp-Py ores (Table 2), lenticular-type orebodies in the DB and JJB that do not contain Sp are lower grade. The concentration of In increases outward from lower-grade mineralization of Types 1-5 in contact zones and the carbonate xenolith. This variation reflects changing physio-chemical conditions from early skarn to later stage hydrothermal mineralization that affected the precipitation of In at the Qibaoshan deposit. Indium is difficult to substitute into magnetite and typical skarn minerals (Figure 5), but appropriate temperatures during the hydrothermal stage allowed for the substitution of In into sphalerite or chalcopyrite of the Type-6 ores.

\subsection{Indium Mineralization in Sn-Poor deposits}

Indium-rich deposits in southern China are related to igneous rocks, yet little geochemical data exist to support a direct connection between the two. As In is a highly volatile chalcophile element, the source for both In and $\mathrm{Cu}$ in magmatic-hydrothermal deposits is likely to be igneous rocks [61-63]. The Qibaoshan deposit is a skarn deposit related to quartz porphyry intrusions, and geochemical data indicate ore-forming components had a magmatic source. It is inferred that In was derived from the 
quartz porphyry. Therefore, In-enriched magma is a critical element in a genetic model of the In-rich and Sn-poor Qibaoshan deposit.

Magmatic processes that concentrate In are more effective in the case of shallow-level intrusions [6]. This is recognized in south China at the Dachang and Yejiwei In-rich deposits (Figure 1a), which formed in a shallow environment [6,55]. Hundreds of small and shallow intrusions, including the Qibaoshan quartz porphyry, are exposed within the NEH (Figure 1b). At the Qibaoshan deposit, In mineralization is closely associated with a shallow-level intrusive complex. Therefore, important elements in the genesis of the Qibaoshan Sn-poor but In-rich orebodies include an In-enriched magma, shallow emplacement of intrusions, and a structural control on mineralization.

\section{Conclusions}

The Qibaoshan is a Sn-poor, In-rich skarn deposit in NEH of China. Salient points concerning In mineralization at the Qibaoshan deposit, based on geologic relationships and ore geochemistry, are as follows:

(1) Indium contents of Sp-Py ores in vein-type orebodies of the LB and XB range from 28.9 to 203.0 ppm (average $122.8 \mathrm{ppm}$ ) which is higher than other ore types in lenticular-type orebodies of the LB, DB, and JGB. Tin concentrations of 10-150 ppm are characteristic of all ore types, with most samples containing $<70 \mathrm{ppm}$ Sn.

(2) The strong correlation between In and each of $\mathrm{Zn}$ and $\mathrm{Cd}$, but poor correlation with $\mathrm{Sn}$, indicates In is hosted mainly in sphalerite. Paragenetic relationships for ore minerals record how sphalerite formed from late quartz-sulfide stage. The distribution of In at the Qibaoshan deposit shows that vein-type orebodies are richer than lenticular-type orebodies occurring at contact zones or within the carbonate xenoliths.

(3) Magmatic processes occurring at a shallow depth that concentrated In in quartz porphyry and structural controls on mineralization were important factors in the formation of Sn-poor and In-rich orebodies of the Qibaoshan deposit.

Acknowledgments: This work was jointly supported by the Innovation-driven Plan in Central South University (Grant 2015CX008), the National Natural Science Foundation of China (Grant 41302048), and the Open Fund of Key Laboratory of Mineralogy and Metallogeny, Chinese Academy of Sciences (Grant KLMM20110103). The author is grateful for Shugen Zhang (School of Geosciences and Info-physics, Central South University), Shunso Ishihara (Geological Survey of Japan), and three reviewers for their valuable comments that greatly improved the manuscript.

Conflicts of Interest: The author declares no conflict of interest.

\section{References}

1. Schwarz-Schampera, U.; Herzig, P.M. Indium: Geology, Mineralogy, and Economics; Springer: Berlin, Germany, 2002.

2. Ishihara, S.; Hoshino, K.; Murakami, H.; Endo, Y. Resource evaluation and some genetic aspects of indium in the Japanese ore deposits. Resour. Geol. 2006, 56, 347-364. [CrossRef]

3. Chakhmouradian, A.R.; Smith, M.P.; Kynicky, J. From "strategic" tungsten to "green" neodymium: A century of critical metals at a glance. Ore Geol. Rev. 2015, 64, 455-458. [CrossRef]

4. Ishihara, S.; Endo, Y. Indium and other trace elements in volcanogenic massive sulfide ores from the Kuroko, Besshi and other types in Japan. Bull. Geol. Surv. Jpn. 2007, 58, 7-22. [CrossRef]

5. Li, X.; Yang, F.; Chen, Z.; Bu, G.; Wang, Y. A tentative discussion on geochemistry and genesis of indium in Dachang tin ore district, Guangxi. Miner. Depos. 2010, 29, 903-914. ((In Chinese)

6. Ishihara, S.; Murakami, H.; Li, X. Indium concentration in zinc ores in plutonic and volcanic environments: Examples at the Dulong and Dachang mines, South China. Bull. Geol. Surv. Jpn. 2011, 62, 259-272. [CrossRef]

7. Pi, Q.; Hu, R.; Wang, D.; Miao, D.; Qin, X.; Chen, H. Enrichment of indium in west ore belt of Dachang orefield: Evidence from ore textures and sphalerite geochemistry. Miner. Depos. 2015, 34, 379-396. (In Chinese)

8. Ishihara, S.; Murakami, H.; Marquez-Zavalia, M. Inferred indium resources of the Bolivian tin-polymetallic deposits. Resour. Geol. 2011, 61, 174-191. [CrossRef] 
9. Oliveira, D.; Rosa, D.; Figueiredo, M. Renewable energy technologies for the 21st century: The Iberian Pyrite Belt as a possible supplier of indium. In Proceedings of the 9th Biennial SGA Meeting of the Society for Geology Applied to Mineral Deposits Meeting, Dublin, Ireland, 20-23 August 2007; pp. 1263-1266.

10. Oliveira, D.; Rosa, D.; Matos, J.; Guimaraes, F.; Figueiredo, M.; Silva, T. Indium in the LagoaSalgada orebody, Iberian pyrite belt, Portugal. In Proceedings of the 10th Biennial SGA Meeting of the Society for Geology Applied to Mineral Deposits Meeting, Townsville, Australia, 17-20 August 2009; pp. 424-426.

11. Oliveira, D.; Matos, J.; Rosa, C.; Rosa, D.; Figueiredo, M.; Silva, T.; Guimaraes, F.; Carvalho, J.; Pinto, A.; Relvas, J.; et al. The LagoaSalgada orebody, Iberian Pyrite Belt, Portugal. Econ. Geol. 2011, 106, 1111-1128. [CrossRef]

12. Zhang, Q.; Zhu, X.; He, Y.; Jiang, J.; Wang, D. Indium enrichment in the Meng'entaolegai Ag-Pb-Zn deposit, Inner Mongolia, China. Resour. Geol. 2006, 56, 337-346. [CrossRef]

13. Fouquet, Y.; von Stackelberg, U.; Charlou, J.L.; Erzinger, J.; Herzig, P.M.; Miihe, R.; Wiedicke, M. Metallogenesis in back-arc environments: The Lau basin example. Econ. Geol. 1993, 88, 2154-2181. [CrossRef]

14. Binns, R.A.; Scott, S.D. Actively forming polymetallic sulfide deposits associated with felsic volcanic rocks in the Eastern Manus Back-Arc Basin, Papua New Guinea. Econ. Geol. 1993, 88, 2226-2236. [CrossRef]

15. Fouquet, Y.; Wafik, A.; Cambon, P.; Mevel, C.; Meyer, G.; Gente, P. Tectonic setting and mineralogical and geochemical zonation in the Snake Pit sulfide deposit (Mid-Atlantic ridge at $23^{\circ} \mathrm{N}$ ). Econ. Geol. 1993, 88, 2018-2036. [CrossRef]

16. Kovalenker, V.A.; Laputina, I.P.; Znamenskii, V.S.; Zotov, I.A. Indium mineralization of the Great Kuril Island Arc. Geol. Ore Depos. 1993, 35, 491-495.

17. Yudovskaya, M.A.; Distler, V.V.; Chaplygin, I.V.; Mokhov, A.V.; Trubkin, N.V.; Gorbacheva, S.A. Gaseous transport and deposition of gold in magmatic fluid: Evidence from the active Kudryavy volcano, Kurile Islands. Miner. Depos. 2006, 40, 828-848. [CrossRef]

18. Liu, J.; Gu, X.; Shao, Y.; Feng, Y.; Lai, J. Indium mineralization in copper-Tin stratiform skarn ores at the Saishitang-Rilonggou ore field, Qinghai, Northwest China. Resour. Geol. 2016, 66, 351-367. [CrossRef]

19. Liang, T.; Wang, D.; Cai, M.; Fan, S.; Yu, Y.; Wei, K.; Huang, H.; Zheng, Y. Metallogenic characteristics and ore-forming regularity of metallic deposits along Nandan-Hechi metallogenic belt in Northwestern Guangxi. Miner. Depos. 2014, 33, 1171-1192. (In Chinese)

20. Li, Y.; Tao, Y.; Zhu, F.; Liao, M.; Xiong, F.; Deng, X. Distribution and existing state of indium in the Gejiu tin polymetallic deposit, Yunnan Province, SW China. Chin. J. Geochem. 2015, 34, 469-483. [CrossRef]

21. Cheng, Y.; Mao, J.; Liu, P. Geodynamic setting of Late Cretaceous Sn-W mineralization in southeastern Yunnan and northeastern Vietnam. Solid Earth Sci. 2016, 1, 79-88. [CrossRef]

22. He, S.; Han, G.; Sun, M.; Hong, Z. Preliminary study of dispersed elements in the Qibaoshan polymetallic ore deposit, Hunan. Geol. Rev. 1985, 81, 143-148. (In Chinese)

23. Qian, D.; Zhang, S.; Wang, Z. The Discovery History of Mineral Deposits of China (Hunan Volume); Geological Publishing House: Beijing, China, 1996. (In Chinese)

24. Ishihara, S.; Qin, K.; Wang, Y. Resource evaluation of indium in the Dajing tin-polymetallic deposits, Inner Mongolia, China. Resour. Geol. 2008, 58, 72-79. [CrossRef]

25. Liu, H.; Zhang, L.; Jin, W.; Shen, K.; Gao, Y. The Yanshanian granitoids in northeast Hunan. Geol. Miner. Resour. South China 1999, 15, 1-9. (In Chinese)

26. Jin, W.; Liu, H.; Zhang, L.; Shen, K. Study on rock-and ore-controlling structures in northeastern Hunan Province. Geol. Miner. Resour. South China 2000, 16, 51-57. (In Chinese)

27. He, Z.; Xu, D.; Chen, G.; Xia, B.; Li, P.; Fu, G. Gold-polymetallic ore-forming geochemistry of Yanshanian intracontinental collision orogen, northeastern Hunan Province. Miner. Depos. 2004, 23, 39-51. (In Chinese)

28. Lu, Y.; He, S. Geology and Metallogeny of the Qibaoshan Polymetallic Ore Deposit in Liuyang County, Hunan Province; No. 402 Geological Team of the Hunan Bureau of Geology and Mineral Resources: Changsha, China, 1984. ((In Chinese)

29. Xu, D.; Wang, L.; Li, P.; Chen, G.; He, Z.; Fu, G.; Wu, J. Petrogenesis of the Lianyunshan granites in northeastern Hunan Province, South China, and its geodynamic implications. Acta Petrol. Sin. 2009, 25, 1056-1078. (In Chinese)

30. Li, P.; Chen, G.; Xu, D.; He, Z.; Fu, G. Petrological and geochemical characteristics and petrogenesis of neoproterozoic peraluminous granites in Northeastern Hunan Province. Geotecton. Metallog. 2007, 31, 126-136. (In Chinese) 
31. Li, P.; Xu, D.; Chen, G.; Xia, B.; He, Z.; Fu, G. Constraints of petrography, geochemistry and Sr-Nd isotopes on the Jinjing granitoids from northeastern Hunan Province, China: Implications for petrogenesis and geodynamic setting. Acta Petrol. Sin. 2005, 21, 921-934. (In Chinese)

32. Shen, C.; Mei, L.; Min, K.; Raymond, J.; Lothar, R.; Yang, Z.; Peng, L.; Liu, Z. Multi-chronometric dating of the Huarong granitoids from the middle Yangtze Craton: Implications for the tectonic evolution of eastern China. J. Asian Earth Sci. 2012, 52, 73-87. [CrossRef]

33. Ji, W.; Lin, W.; Michel, F.; Chen, Y.; Chu, Y.; Xue, Z. Origin of the Late Jurassic to Early Cretaceous peraluminous granitoids in the northeastern Hunan Province (middle Yangtze region), South China: Geodynamic implications for the Paleo-Pacific subduction. J. Asian Earth Sci. 2016, in press. [CrossRef]

34. Liu, H.; Jin, W.; Zhang, L.; Shen, K. Discussion on sources of metallogenetic materials of porphyry-type and hydrothermal copper deposits in northeastern Hunan Province. Geol. Miner. Resour. South China 2001, 17, 40-47. (In Chinese)

35. Fu, G.; Xu, D.; Chen, G. New recognitions on geological characteristics of gold ore deposits in northeastern Hunan Province, China and new prospecting advances. Geotecton. Metallog. 2002, 26, 416-422. (In Chinese)

36. Deng, T.; Xu, D.; Chi, G.; Wang, Z.; Jiao, Q.; Ning, J.; Dong, G.; Zou, F. Geology, geochronology, geochemistry and ore genesis of the Wangu gold deposit in northeastern Hunan Province, Jiangnan orogen, of South China. Ore Geol. Rev. 2017, in press. [CrossRef]

37. Xu, D.; Deng, T.; Chi, G.; Wang, Z.; Zou, F.; Zhang, J.; Zou, S. Gold mineralization in the Jiangnan orogenic belt South China: Geological, geochemical and geochronological characteristics, ore deposit-type and geodynamic setting. Ore Geol. Rev. 2017, in press. [CrossRef]

38. Wang, Y.; Zhu, J.; Yu, Q. Geology of Lead-Zinc Deposits in Hunan Province; Geological Publishing House: Beijing, China, 1988. (In Chinese)

39. Yi, Z.; Luo, X.; Zhou, D.; Xiao, C. Geological characteristics and genesis of Jinchong Co-Cu polymetallic deposit, Liuyan, Hunan Province. Geol. Miner. Resour. South China 2010, 26, 12-18. (In Chinese)

40. Wang, Z.; Xu, D.; Chi, G.; Shao, Y.; Lai, J.; Deng, T.; Guo, F.; Wang, Z.; Dong, G.; Ning, J.; Zou, S. Mineralogical and isotopic constraints on the genesis on the Jingchong Co-Cu polymetallic in northeastern Hunan Province, South China. Ore Geol. Rev. 2017, in press. [CrossRef]

41. Lu, Y.; Yin, H.; Shen, R. Genetic model of the Qibaoshan polymetallic ore deposit in Hunan Province. Miner. Depos. 1984, 3, 53-60. (In Chinese)

42. Hu, X.; Peng, E.; Sun, Z. Geological characteristics and genesis of the Qibaoshan Cu-polymetallic deposit. Geotecton. Metallog. 2000, 24, 365-370. (In Chinese)

43. Yang, R.; Fu, G.; Chen, B.; Chen, J.; Si, C.; Liu, B.; Zheng, Z. Qibaoshan Cu-polymetallic deposit in Hunan Province and its prospecting orientation. Geol. Miner. Resour. South China 2015, 31, 246-252. (In Chinese)

44. He, S.; Sun, M. The study of polymetallic ore characteristics and useful elements in Qibaoshan. Geol. Prospect. 1986, 22, 28-35. (In Chinese)

45. Zhang, G.; Liu, R. Evaluation for mine geological environment of the Xiaoqibaoshan Cu-Zn deposit in Liuyang, Hunan. Land Resour. Her. 2006, 3, 35-37. (In Chinese)

46. $\mathrm{Hu}, \mathrm{J} . ; \mathrm{Xu}, \mathrm{D}$; Zhang, K. Zircon U-Pb dating, Hf isotope of magmatic rocks from the Qibaoshan $\mathrm{Cu}$ polymetallic deposit, Hunan. Geol. Miner. Resour. South China 2015, 31, 236-245. (In Chinese)

47. $\mathrm{Hu}, \mathrm{J} . ; \mathrm{Xu}, \mathrm{D}$; Zheng, K. Geochemistry of quartz-porphyry and its relationship with mineralization in the Qibaoshan deposit, Hunan Province. Geol. Miner. Resour. South China 2012, 28, 298-306. (In Chinese)

48. Hu, X.; Xiao, X.; Yang, Z. Geological and geochemical features of the Qibaoshan granite-porphyry. J. Cent. South Univ. Technol. 2002, 33, 552-554. (In Chinese)

49. Hu, X.; Yang, Z. Ore-forming fluid characteristics and evolution process of the Qibaoshan Cu-polymetallic deposit in Liuyang, Hunan. Geol. Prospect. 2003, 39, 22-25. (In Chinese)

50. Han, G.; He, S.; Sun, M.; Huang, Z. Gold and silver minerals and forming condition in polymetallic ore deposit from Qibaoshan, Liuyang, Hunan. J. Miner. Petrol. 1985, 6, 97-103. (In Chinese)

51. Sun, M.; Han, G.; He, S.; Huang, Z. Tetradymite in Liuyang ore deposit. Acta Miner. Sin. 1985, 5, 76-79. (In Chinese)

52. He, S. Joseite-B in the Qibaoshan polymetallic deposit. Hunan Geol. 1993, 12, 43-45. (In Chinese)

53. Zheng, L.; Gu, X.; Cao, H.; Li, Q. Geological and geochemical characteristics of the Qibaoshan Ca-skarn and Mg-skarn intergrowth-type polymetallic deposit in Hunan Province. Geoscience 2014, 28, 87-97. (In Chinese) 
54. Yang, Z.; Peng, S.; Hu, X.; Li, C. Ore-forming fluid inclusion characteristics and metallogeny of the Qibaoshan Cu-polymetallic deposit in Liuyang, Hunan. J. Earth Sci. Environ. 2004, 26, 11-15. (In Chinese)

55. Liu, J.; Rong, Y.; Gu, X.; Shao, Y.; Lai, J.; Chen, W. Indium mineralization in the Yejiwei Sn-polymetallic deposit of the Shizhuyuan Orefield, southern Hunan, China. Resour. Geol. 2007, submitted.

56. Andersen, J.C.Ø.; Stickland, R.J.; Rollinson, G.K.; Shail, R.K. Indium mineralisation in SW England: Host parageneses and mineralogical relations. Ore Geol. Rev. 2016, 78, 213-238. [CrossRef]

57. Ishihara, S.; Matsueda, H. Chemical characteristics of the indium-polymetallic ores from the Toyoha mine, Hokkaido, Japan. Bull. Geol. Surv. Jpn. 2011, 62, 131-142. [CrossRef]

58. Murakami, H.; Ishihara, S. Trace elements of indium-bearing sphalerite from tin-polymetallic deposits in Bolivia, China and Japan: A femto-second LA-ICPMS study. Ore Geol. Rev. 2013, 53, 223-243. [CrossRef]

59. Zhang, Q.; Zhu, X.; He, Y.; Zhu, Z. In, $\mathrm{Sn}, \mathrm{Pb}$ and $\mathrm{Zn}$ contents and their relationships in ore-forming fluids from some In-rich and In-poor deposits in China. Acta Geol. Sin. 2007, 81, 450-462.

60. Sinclair, W.D.; Kooiman, G.J.A.; Martin, D.A.; Kjarsgaard, I.M. Geology, geochemistry and mineralogy of indium resources at Mount Pleasant, New Brunswick, Canada. Ore Geol. Rev. 2006, 28, 123-145. [CrossRef]

61. Cook, N.J.; Sundblad, K.; Valkama, M.; Nygård, R.; Ciobanu, C.L.; Danyushevsky, L. Indium mineralization in A-type granites in southeastern Finland: Insights into mineralogy and partitioning between coexisting minerals. Chem. Geol. 2011, 284, 62-73. [CrossRef]

62. Simons, B.; Andersen, J.C.Ø.; Shail, R.K.; Jenner, F. Fractionation of Li, Be, Ga, Nb, Ta, In, Sn, Sb, W and Bi in the peraluminous Early Permian Variscan granites of the Cornubian Batholith: Precursor processes to magmatic-hydrothermal mineralization. Lithos 2017, 278, 491-512. [CrossRef]

63. Seifert, T.; Sandmann, D. Mineralogy and geochemistry of indium-bearing polymetallic vein-type deposits: Implications for host minerals from the Freiberg district, Eastern Erzgebirge, Germany. Ore Geol. Rev. 2006, 28, 1-31. [CrossRef]

(C) 2017 by the author. Licensee MDPI, Basel, Switzerland. This article is an open access article distributed under the terms and conditions of the Creative Commons Attribution (CC BY) license (http:/ / creativecommons.org/licenses/by/4.0/). 